\title{
Structure and Miocene evolution of the Gdów tectonic "embayment" (Polish Carpathian Foredeep) - a new model based on reinterpreted seismic data
}

\author{
Piotr KRZYWIEC, Krzysztof BUKOWSKI, Nestor OSZCZYPKO and Aleksander GARLICKI
}

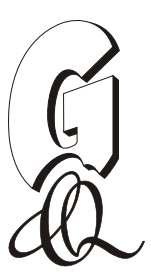

Krzywiec P., Bukowski K., Oszczypko N. and Garlicki A. (2012) - Structure and Miocene evolution of the Gdów tectonic “embayment" (Polish Carpathian Foredeep) - a new model based on reinterpreted seismic data. Geol. Quart., 56 (4): 907-920, doi: 10.7306/gq.1067

\begin{abstract}
Analysis of previously available stratigraphic data coupled with the re-interpretation of seismic profiles calibrated by boreholes has allowed the construction of a new tectonic model of evolution of the Gdów "embayment" - a tectonic re-entrant located along the Carpathian front east of Kraków (southern Poland). This model shows that the main phase of localized fault-controlled subsidence took place in the Early Badenian and was associated with deposition of the locally overthickened Skawina Formation. Also, deposition of evaporites of the Wieliczka Formation seems to have been tectonically controlled by local basement faulting. Supra-evaporitic siliciclastic deposits have developed as a result of overall north-directed sediment progradation from the eroded Carpathian belt towards the Carpathian Foredeep. During the final stages of development of the Carpathian fold-and-thrust wedge the previously subsiding Gdów "embayment" area was uplifted and basement faults were reactivated either as reverse faults or as low angle thrust faults Along the leading edge of this inverted structure a triangle zone developed, with backthrusting along the evaporitic level. As a result, overthickened evaporites, formed in local tectonically-controlled depressions within the area of the Gdów "embayment" area have been strongly folded and internally deformed.
\end{abstract}

Piotr Krzywiec, Institute of Geological Sciences, Polish Academy of Sciences, Twarda 51/55, 00-818 Warszawa, Poland, e-mail: piotr.krzywiec@twarda.pan.pl; Krzysztof Bukowski and Aleksander Garlicki, Faculty of Geology, Geophysics and Environmental Protection, AGH University of Science and Technology, Mickiewicza 30, 30-059 Kraków, Poland, e-mails: buk@agh.edu.pl, kcyran@geolog.geol.agh.edu.pl; Nestor Oszczypko, Institute of Geological Sciences, Jagiellonian University, Oleandry 2A, 30-063 Kraków, Poland, e-mail: nestor_oszczypko@yahoo.com (received: June 28, 2012; accepted: December 12, 2012; first published online: December 19, 2012).

Key words: Carpathian Foredeep Basin, Gdów “embayment”, Miocene, wedge tectonics.

\section{INTRODUCTION}

The trailing edge of the Carpathian fold-and-thrust belt between Kraków and Tarnów has been the subject of intense studies because of its control over deposits of rock salt (e.g., Wieliczka and Bochnia salt mines) and hydrocarbon accumulations. Frontal thrust sheets of the Outer (flysch) Carpathians south of Kraków include the Silesian and Subsilesian nappes (Fig. 1). Further to the north, a relatively narrow zone of the deformed Miocene Carpathian Foredeep deposits is located, forming the Zgłobice thrust-sheet (Kotlarczyk, 1985; cf. Oszczypko et al., 2006 for extensive review and numerous references). Miocene foredeep deposits are also present within the so-called Gdów "embayment", analysed in this paper.

Transgression of the Early Miocene sea of the Carpathian Foredeep Basin covered both the foreland platform and in part the Outer Carpathian thrust sheets. During the development of this sedimentary basin (Badenian-Sarmatian; Fig. 2), marine sedimentation prevailed. Only the late Badenian salinity crisis associated with deposition of evaporites (rock salt, gypsum) marked significant shallowing of the basin.

In the Early Badenian the axial part of the basin reached upper bathyal depths, while the northern and southern parts of the basin were within the neritic-littoral zone (cf. Oszczypko et al., 2006). Gradual shallowing of the basin began in Serravalian times (Andreyeva-Grigorovich et al., 2003). Results of recent ${ }^{40} \mathrm{Ar} /{ }^{39} \mathrm{Ar}$ dating indicate that deposition of the evaporites in the Carpathian Foredeep Basin started shortly after $13.81 \pm$ $0.076 \mathrm{Ma}$ (de Leeuw et al., 2010) and thus directly after Mi3b, a major step in the Middle Miocene global cooling, dated in the Mediterranean region at 13.82 $\pm 0.03 \mathrm{Ma}$ (Abels et al., 2005). Isotopic data of Badenian foraminifera indicate a sharp decrease in seawater temperature just below the evaporites 


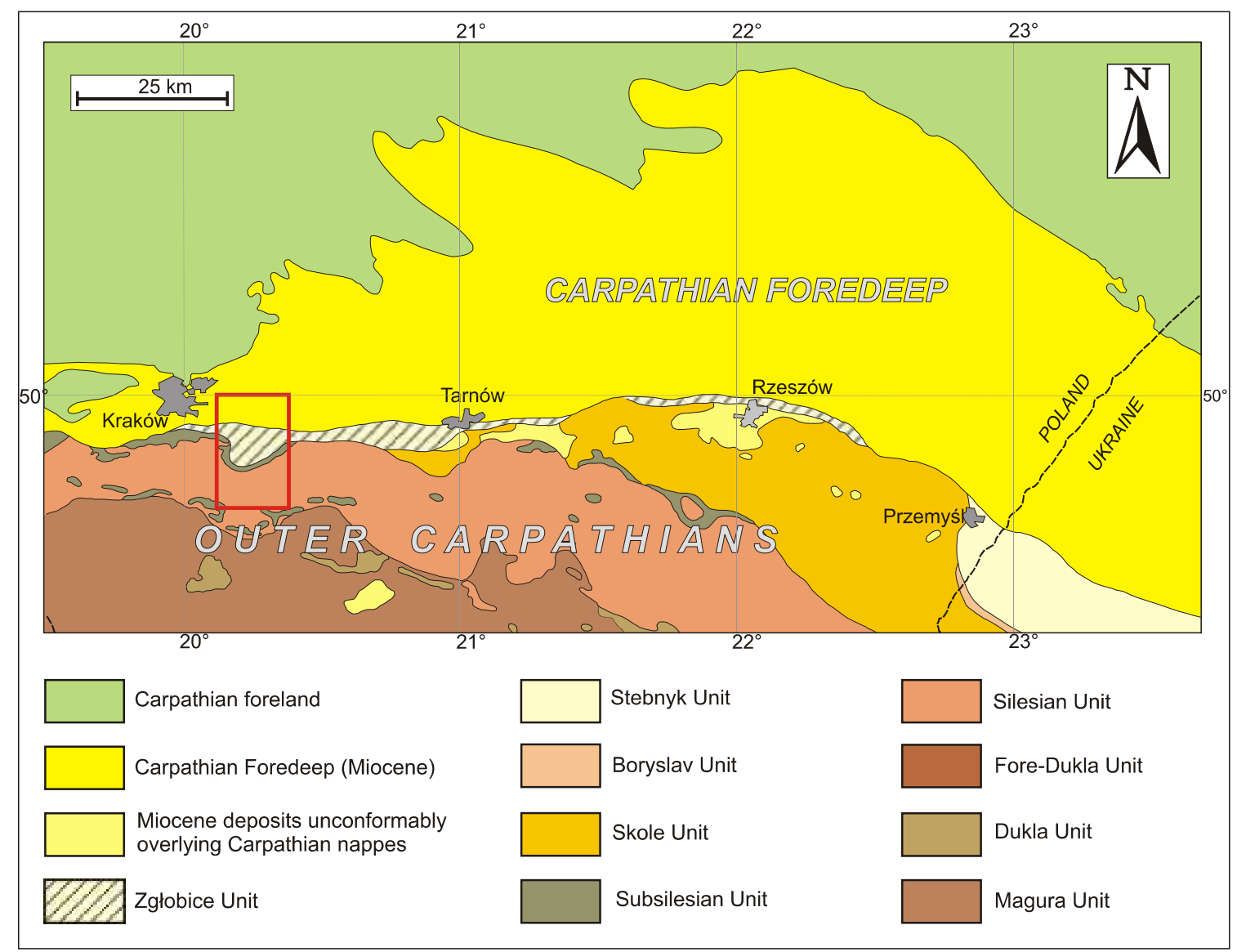

Fig. 1. Simplified geological map of the Outer Carpathians and their foreland between Kraków and Przemyśl

Red rectangle - area shown on Figure 3

(Gonera et al., 2000; Bicchi et al., 2003; Peryt and Gedl, 2010; Bukowski, 2011; Gonera and Bukowski, 2012), also in agreement with the globally recognized Mi3b cooling event (de Leeuw et al., 2010). The drop in global sea level at Mi3b caused the final closure of the existing gateways between the Central Paratethys and the Mediterranean part of the Tethys. Sea level lowering likely restricted the deep outflow of dense saline waters from the Carpathian Foredeep, trapping the salt within the Paratethys basins and consequently setting off the Badenian salinity crisis (de Leeuw et al., 2010; Bukowski, 2011).

Shallow parts of the evaporite basin were dominated by sulphate and subordinary carbonate-littoral facies (e.g., Kasprzyk, 1993; Peryt et al., 1997; Bąbel, 2004; Jasionowski and Peryt, 2010). Deeper parts of basin, located along the Carpathian front, were occupied by chloride-sulphate facies - rock salts of the Wieliczka Formation (Fig. 2; see Garlicki, 1979; Peryt, 2006). According to Bąbel (2004), the gypsum sub-basin was very shallow, zero to several metres deep, whilst the depth of the halite sub-basin was estimated at not less than 30-40 m.

After the Badenian salinity crisis, the edge of the Carpathian thrust belt moved by a few kilometres to the north (see Oszczypko, 1997, 1998; Kováč et al., 1998; Oszczypko and Oszczypko-Clowes, 2012). At the front of the Carpathian orogen this resulted in a deepening of the basin, which reached depths characteristic for the outer shelf, during the deposition of the clayey sediments of the Chodenice Beds (Gonera, 1994; Kovač et al., 1998; Oszczypko, 1999). At the same time the high level of the sea caused extensive marine transgresssion onto the Outer Carpathian thrust sheets, including the Magura Nappe. This is marked in the Nowy Sącz Basin by transgressive neritic deposits (NN6/7 Zone) over the freshwater Biegonice Formation (Oszczypko et al., 1992; Oszczypko-Clowes et al., 2009).

The zone of maximum subsidence within the Carpathian Foredeep Basin migrated in Sarmatian times ca. $40-50 \mathrm{~km}$ towards the NE, towards the Teisseyre-Tornquist Zone that was reactivated due to foreland flexural extension (cf. Krzywiec, 2001; Oszczypko et al., 2006; Gągała et al., 2012).

The frontal thrust of the Outer (flysch) Carpathian orogenic front in the area south-east of Kraków recedes to the south, forming a "bay" or "embayment", termed by Niedźwiedzki (1883-1886) the Gdów embayment, after the town of Gdów (Fig. 3). The surface and shallow subsurface geometry of this area prompted Niedźwiedzki (1883-1886) to propose that in Miocene times the frontal Carpathian thrust did indeed form a bay filled by the Miocene sea. Subsequent studies (see below) have clearly shown that this original concept was in error and that this retreat of the frontal Carpathian thrust was due to combination of tectonics, uplift and erosion. In order, however, to 


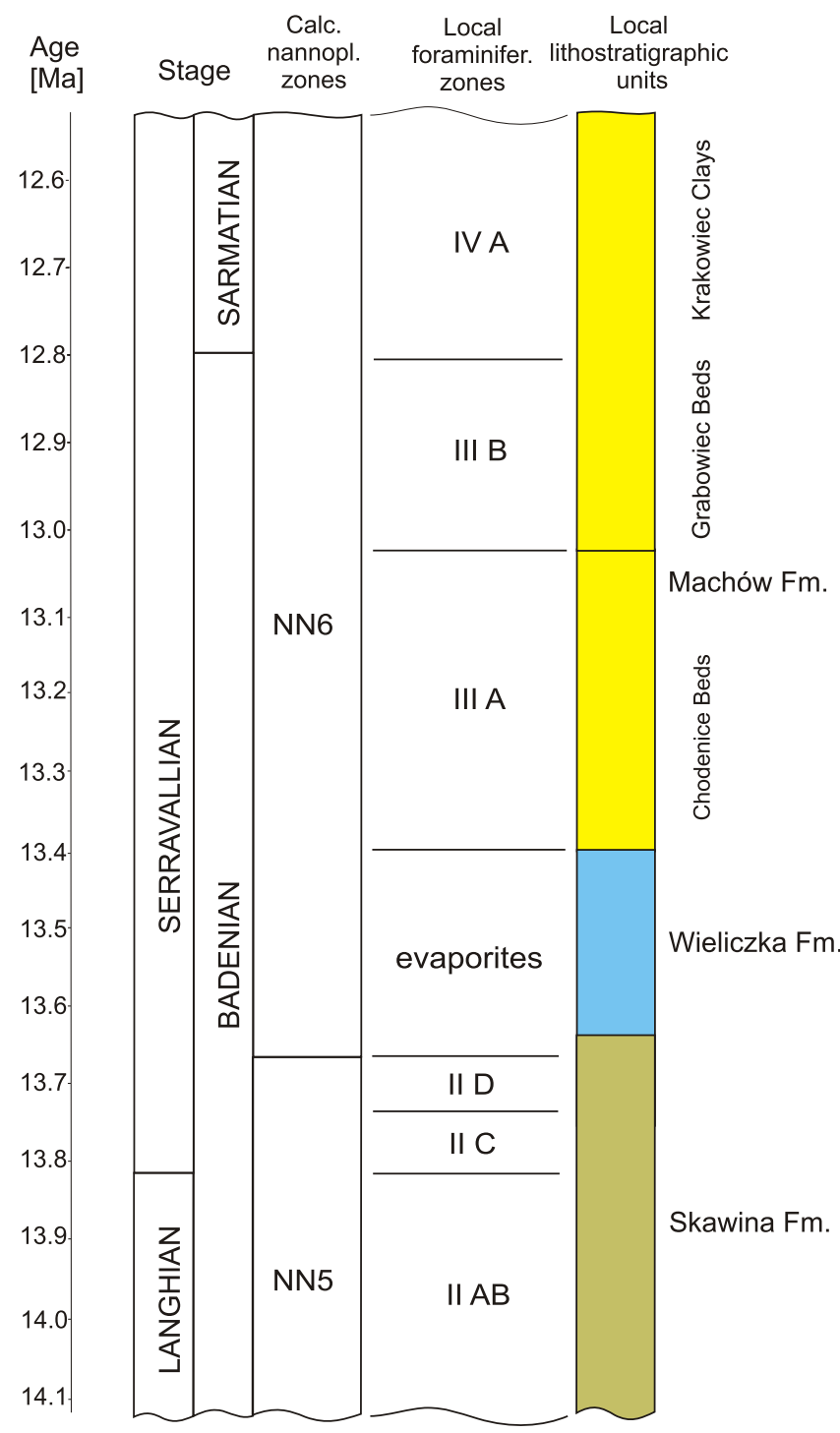

Fig. 2. The local Carpathian Foredeep Middle Miocene stratigraphy in comparison with the standard global chronostratigraphy (GSSP after Hilgen et al., 2009)

Calcareous nannoplankton NN zones after Peryt (1997) and Raffi et al (2006), local foraminiferal zones after Alexandrowicz (1963); position of the Chodenice Beds after de Leeuw et al. (2010) and Śliwiński et al. (2012); notice that de Leeuw et al. (2010) put the base of evaporites at $13.81 \pm 0.076 \mathrm{Ma}$; colours used to depict local lithostratigraphic units match those used on Figures 4-6 and 8

maintain compatibility with the previous nomenclature, the term "embayment" will be used through this paper, although it should not be understood in its original strict meaning, coined by Niedźwiedzki (1883-1886).

The Miocene deposits of the Gdów "embayment" consist mostly of clays and shales, with subordinate sands. They are all included in the Lower Badenian sub-evaporitic deposits (Połtowicz, 1962; Alexandrowicz, 1965; Moryc, 1970a, b). Alexandrowicz (1965) divided this succession into four foraminiferal levels IIA, IIB, IIC, IID, and proposed the name Skawina Beds (Alexandrowicz, 1963). Later, the term "Skawina Beds" has been extended and defined as the "Skawina Formation" (Ale- xandrowicz et al., 1982). The beginning of Skawina Formation deposition is dated to the Lower Badenian Orbulina suturalis Zone (see Oszczypko et al., 2006). In the southern part of the Gdów "embayment" the Skawina Fm. has been drilled beneath the Outer Carpathians in borehole Łapanów 1 in the depth interval $1.458-1.765 .5 \mathrm{~m}$. In the upper part of the Skawina Formation, late Badenian calcareous nannoplankton belonging to the lower part of NN6 Zone have been determined (Peryt, 1997; Oszczypko and Oszczypko-Clowes, 2012). The same NN6 nanoplankton assemblages have been described from the sub-evaporitic Skawina Formation in the Bochnia and Kalush Salt Mine (Andreyeva-Grigorovich et al., 2003; Fig. 2).

In the southern part of the Gdów "embayment” (i.e. Gdów 1 and Gdów 2 boreholes; Fig. 3) a significant increase in the amount of sands and gravels is observed. The same coarse clastic deposits are also known from outcrops in the Sypka Góra village, near Gdów, where gravels with flysch material occur (cf. Jasionowski, 1997). Their thickness reaches at least 40 metres; they have been interpreted as having formed on gravel deltas (Doktor, 1983). The Lower Badenian foraminiferal assemblages IIA-IIC have been identified in these deposits (Alexandrowicz, 1965). Similar flysch gravels, occurring directly below the evaporites, were described from the marginal zone of the Carpathian Foredeep, in Wrząsowice (Gonera et al., 1990) and Bacharowice (Doktor, 1983), south of Kraków.

This paper consists of two main parts. The first is devoted to critical analysis of main previously published tectonic models of the Gdów "embayment" area in order to provide a historical perspective for geological studies of the frontal Outer Carpathians east of Kraków, dating back at least to the XVIIIth century. The second part describes a new tectono-stratigraphic model of the evolution of the Gdów "embayment" based on reinterpreted seismic data calibrated by boreholes.

\section{PREVIOUS TECTONIC MODELS OF THE GDÓW "EMBAYMENT"}

The earliest geological studies of the frontal Carpathian orogenic wedge in Poland have focused on the area located immediately east of Kraków, where rock salt has been mined for centuries in Wieliczka and Bochnia salt mines (e.g., Schober; 1750; Townson, 1797; Pusch, 1824; Hrdina and Hrdina, 1842; Niedźwiedzki, 1883-1886; Uhlig, 1903; cf. Poborski, 1965; d'Obyrn and Przybyło, 2010). In the 20th century, exploration for oil and gas greatly intensified and resulted in the acquisition of a large amount of subsurface geophysical data that significantly improved the understanding of the geological structure of the frontal Carpathian fold-and-thrust belt in, among others, Kraków-Tarnów area. Following decades of intense geological and geophysical study, many structural models have been proposed for the frontal Carpathians (see Oszczypko et al., 2006 for detailed overview and further references).

The area of the Gdów "embayment" has been extensively studied: in total, several tens of deep boreholes have been drilled, numerous geophysical studies (gravity, magnetic, seismic) have been made, mostly during exploration for rock salt 


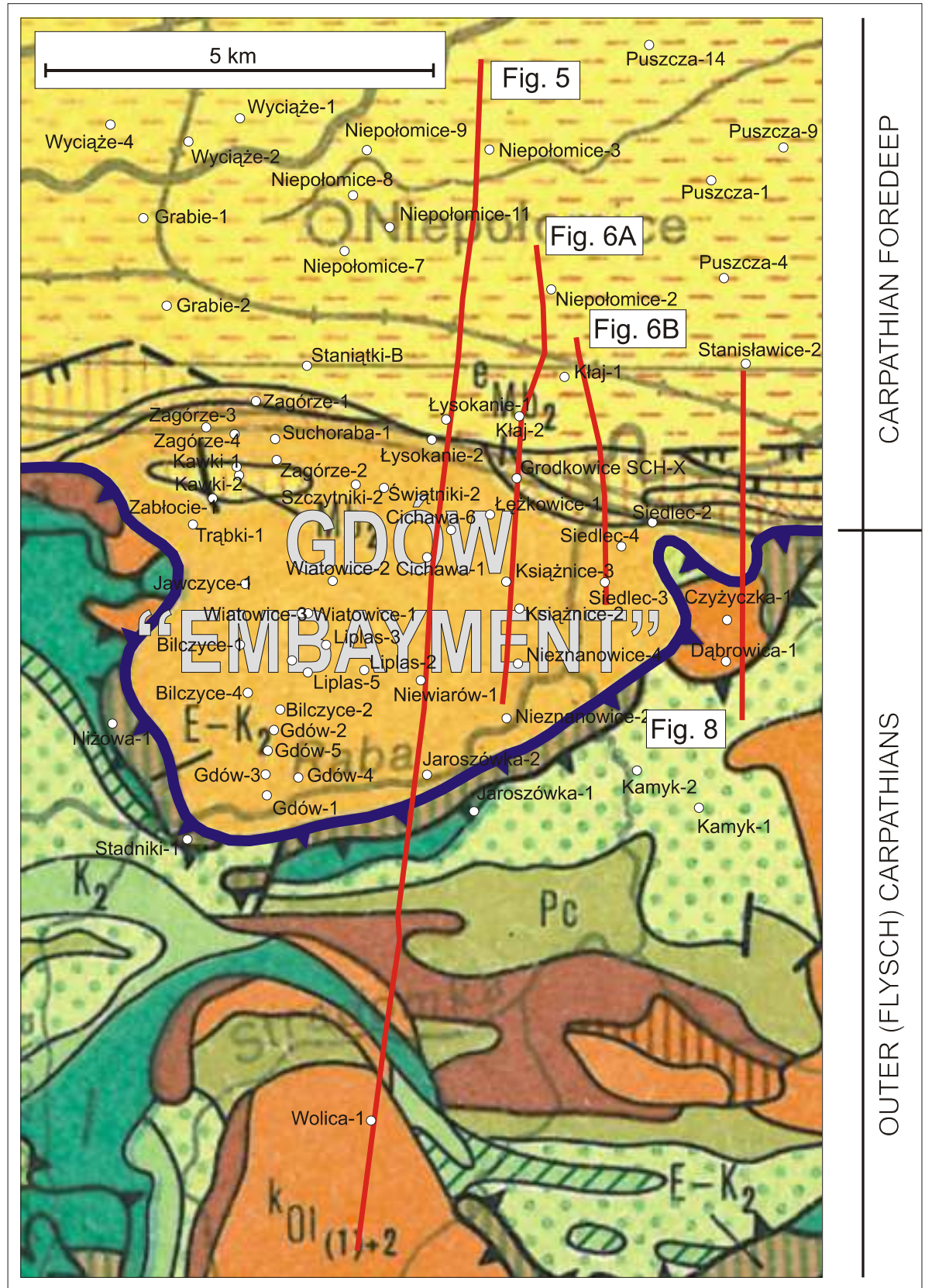

Fig. 3. Location of the interpreted seismic profiles (Figs. 5 and 6), geological cross-section (Fig. 7) and boreholes on a background of a simplified geological map of the Outer Carpathians and their foreland without Quaternary formations (after ytko et al., 1989)

For other explanations see ytko et al. (1989)

and, in more recent years, for hydrocarbons. All the surface and subsurface data have allowed many researchers to come up with different models of the present-day structure and evolution of this part of the Carpathian front. Below, a brief summary of these models is given, that will be consequently used as a reference point for discussion of new results of seismic data interpretation. Previous models of the Gdów "embayment" are presented in chronological order, to illustrate the evolution of the ideas triggered by the increased amount of stratigraphic and tectonic evidence. Selected tectono-stratigraphic models of the Gdów "embayment" that illustrate the evolution of concepts of its geological structure are shown on Figure 4.
The first model that presented, in modern style, the structure of the Gdów "embayment" was published by Garlicki, following intense exploration for rock salt in the Łę kowice Siedlec area (Garlicki, 1960 and his fig. 2). In this model, the Gdów "embayment" is filled by the gently folded Chodenice and Grabowiec beds (cf. Fig. 2) entraining also Miocene evaporites (rock salt). The northern edge of the "embayment" coincides with salt deposits that are deformed, uplifted to the surface and over-thickened. In this model, there is no tectonic deformation within the pre-Miocene basement although this basement is shown by hatched lines indicating uncertain geometry (Garlicki, 1960) - a result of the scarcity of reliable good 


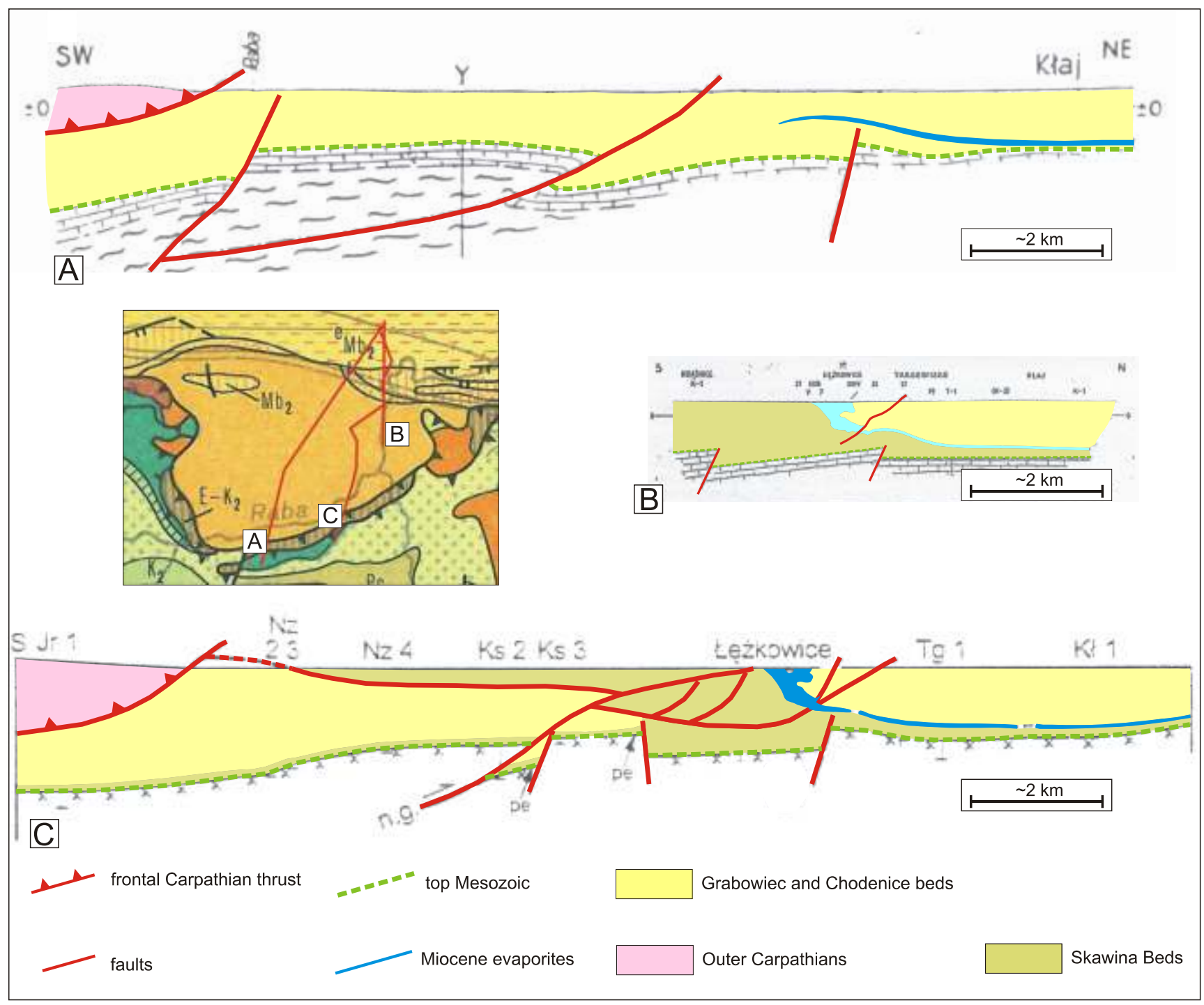

Fig. 4. Geological models of the Gdów "embayment"

A - according to Połtowicz (1962); B - according to Garlicki (1971); C - according to Połtowicz (2004); geological cross-sections are shown at approximately the same scale and are vertically aligned along the approximate location of the Kłaj 1 borehole (cf. Fig. 3); all the key explanations are shown on this figure; for explanations of other symbols see original papers of Połtowicz (1962), Garlicki (1971) and Połtowicz (2004)

quality subsurface data, as this model pre-dates the acquisition of modern digital seismic reflection data.

In 1962, Połtowicz published the next model of the Gdów "embayment", using not only well and surface geological data but also geophysical subsurface information: reflection seismic and geoelectric data (Połtowicz, 1962 and his fig. 4). His model is shown on Figure 4A. Połtowicz, having access to the subsurface geophysical data, first suggested the presence of low angle reverse faults (thrusts) detached within the Mesozoic basement, cutting also the Miocene infill of the Gdów "embayment". Its Miocene sedimentary infill consists of the Chodenice Beds (containing also rock salt deposits), present within the entire "embayment" and overlying the Mesozoic basement. The Grabowiec Beds are present only to the north of the northern edge of the "embayment".

Significant improvement in the geological interpretation of the Gdów "embayment" was fuelled by the detailed biostratigraphic studies of the Miocene foredeep succession in this area. Alexandrowicz (1965; cf. also Doktor, 1983) distinguished the sub-evaporitic succession present within the entire "embayment" as the Skawina Beds (IIA-D foraminiferal zones), with the Chodenic and Grabowiec beds (IIIA, B foraminiferal zones) located entirely above the evaporitic level (Fig. 2; cf. also Łuczkowska, 1958; Olewicz, 1973a, b). This more precise tripartite stratigraphic zonation provided a new reference point for the tectonic analyses of this area, with the evaporitic level defined as a marker horizon located at the boundary between the Skawina Beds and Chodenice Beds. It is also worth mentioning that Miocene foredeep evaporites form an excellent marker in interpretation of the seismic data

In early 1970s Garlicki summarized a decade of geological and geophysical studies of the Gdów "embayment" and presented his new refined tectono-stratigraphic model of the present-day structure of this area and also of its Miocene evolution (Garlicki, 1971; Fig. 4B). He adopted the tripartite stratigraphic model of the Miocene infill established by Alexandrowicz 
(1965) comprising (1) the sub-evaporitic siliciclastic succession (Skawina Beds), (2) evaporites (rock salt), and (3) the supra-evaporitic siliciclastic succession (Chodenice and Grabowiec Beds). In his model (Garlicki, 1971 and his fig. 2) proposed a system of reverse faults rooted in the Meso-Paleozoic basement of the Gdów "embayment". In this model the sedimentary infill, as in the model of Alexandrowicz (1965), consists entirely of the folded sub-evaporitic Skawina Beds characterized by significant thickness, up to several hundreds of metres. Overthickened and strongly deformed (folded) salt deposits are located along the northern edge of the "embayment", where they had been recognized by numerous boreholes in the Łę kowice area (Fig. 3). The supra-evaporitic succession (Chodenice and Grabowiec beds), conformably deposited above the evaporites, is present only to the north of the northern edge of the "embayment". In this area, the sub-evaporitic succession is rather thin, of the order of tens of metres, in contrast to the thick infill of the Gdów "embayment" at the same stratigraphic position. Using his structural model, Garlicki (1971) proposed also a model for the tectono-stratigraphic development of this area (Garlicki, 1971 and his fig. 3). He associated increased thickness of the Skawina Beds with syn-depositional activity of basement faults and related increased local subsidence. Garlicki (1971) postulated also that salt deposits of the Łę kowice area, thicker than in the northern part of the foredeep basin and presently strongly deformed, were deposited during increased tectonically-controlled local subsidence within the future Gdów "embayment" area. Deposition of evaporites was followed by deposition of siliciclastic deposits of the supra-evaporitic succession (Chodenice and Grabowiec beds). According to Garlicki (1971), during later phases of the tectonic evolution of this area, due to the increase orogenic push related to the final phase of development of the Carpathian fold-and-thrust belt, basement normal faults were reactivated as reverse faults, and the entire Miocene foredeep infill of the Gdów "embayment" was folded and thrust towards the north.

Models of the Gdów "embayment" by Alexandrowicz (1965) and Garlicki (1971) were subsequently challenged. According to Poborski and Jawor (1987), almost the entire infill of the Gdów "embayment" consists of the supra-evaporitic Chodenice Beds, with only a thin and incomplete cover of the sub-evaporitic Skawina Beds resting directly above the Mesozoic basement (see Poborski and Jawor, 1987 and their fig. 2). Poborski and Jawor (1987) did not, however, present any stratigraphic evidence in support of their new model although they suggested significant modifications of the previous stratigraphic findings of Łuczkowska (1958) and Alexandrowicz (1965).

In their next paper, Poborski and Jawor (1989) proposed an even more generalized structure of the Gdów "embayment" as they used only the general term "Miocene formation" to describe the entire Miocene infill of the "embayment". Within this formation, the evaporitic level was distinguished as a marker horizon, but no information was given on the precise stratigraphy of the sub- and supra-evaporitic successions.

According to newer models of the Gdów "embayment” by Połtowicz (1991, 2004; Fig. 4C), only the uppermost part (up to $200 \mathrm{~m}$ ) of its sedimentary cover consists of the sub-evapo- ritic Skawina Beds. These sediments form an allochthonous thrust slice tectonically transported above a very flat (almost horizontal) fault (detachment level) to the north. Beneath this slice, the autochthonous cover consists of the thick Chodenice and Grabowiec beds and thin Skawina Beds, resting above the Mesozoic basement. This basement is dissected by several normal and reverse/thrust faults. Połtowicz (1991, 2004), similarly to Poborski and Jawor (1987), did not, however, provide any detailed stratigraphic data that would support his structural model. He only quoted archive unpublished stratigraphic results of Z. Kirchner from unidentified industry wells, without presenting any solid biostratigraphic data or even references to the archive well reports. Taking this into account one can conclude that the structural models of Poborski and Jawor (1987) and Połtowicz (1991, 2004), significantly different from the previous models based on detailed stratigraphic studies (Garlicki, 1971), are not supported by reliable and verifiable stratigraphic data and have to be treated with the great caution.

The Carpathian front in the area located east of Kraków was first described as associated with a triangle zone by Jones (1997). This model was, however, mentioned only in a conference abstract and was not supported by any more comprehensive publication. Recently, a model of wedge tectonics and triangle zones was used in order to explain the structure of the Carpathian front imaged on seismic data from the Wojnicz-Tarnów area, located to the east of the Gdów "embayment" (Krzywiec et al., 2004). Furthermore, it has been also suggested that in the Wieliczka part of the Carpathian front wedge, located to the west of the Gdów "embayment", wedge tectonics also played an important role, and that the entire Wieliczka Salt Mine is located in the core of the triangle zone formed during the last stages of compression within the Carpathian orogenic wedge (Krzywiec and Vergés, 2007). Finally, Bukowski et al. (2010) presented a seismic profile from the Gdów "embayment", reinterpreted using verified stratigraphic data from boreholes and outcrops (including new radiometric dates of tuffites). This seismic profile (Bukowski et al., 2010 and their fig. 9) shows low-angle thrust faults and steep reverse faults detached within the Meso-Paleozoic basement of the Gdów "embayment", and triangle zone and associated backthrusting along its northern edge, similarly to that reported from the Wojnicz-Tarnów area by Krzywiec et al. (2004).

\section{RESULTS OF SEISMIC DATA INTERPRETATION FROM THE GDÓW "EMBAYMENT"}

In order to construct a revised tectono-stratigraphic model of evolution of the Gdów "embayment", seismic data acquired in 1992 by Geofizyka Kraków was used. This seismic data comprised post-stack time migrated profiles, with the reference level ( 0 sec TWT) equal to $170 \mathrm{~m}$ a.s.l. Approximately the first 200 milliseconds of seismic data has been muted due to very low quality and could not have been used for interpretation.

Some of the boreholes drilled in the study area (cf. Fig. 3) had sonic logs and check-shot data available, and this data was used to construct time-depth tables, necessary for precise well-to-seismic tie. 
The general structure of the study area is shown on a regional seismic transect, constructed using several seismic profiles reprocessed by Geofizyka Kraków using original field data (Fig. 5). It shows three main structural domains, important for the analysis described in this paper:

- frontal part of the Outer (flysch) Carpathians,

- Gdów "embayment",

- northern part of the Carpathian Foredeep.

The frontal Outer Carpathian thrust sheet is strongly internally deformed, but its structure and evolution has not been a focus of this paper, and consequently, it was treated en bloc as a tectonic block that was thrust to the north during the final stages of the Carpathian collision. Within the Gdów "embayment", resolution of the seismic data is significantly higher and one can observe there numerous fairly continuous seismic reflectors that precisely depict the internal geometry of this part of the Carpathian thrust belt. Stratigraphic information from numerous boreholes as well as published results of earlier stratigraphic studies show that all the Miocene deposits that cover the Meso-Paleozoic basement of the Gdów "embayment" should be regarded as sub-evaporitic Skawina Beds (cf. Bukowski et al., 2010). Overall thickness changes in the sub-evaporitic Miocene succession within the Gdów "embayment" show a gradual thickness increase generally towards the south. There are also clearly visible faults within the Meso-Paleozoic basement (Fig. 5). One fault, located in the northern part of the Gdów "embayment", may be classified as a low-angle thrust fault that carries Mesozoic (Jurassic) rocks towards the north, above the Skawina Beds (Figs. 5 and 6). Along the trailing edge of the Gdów "embayment" (vicinity of the Łysokanie 1 and 2 boreholes) foredeep evaporites together with overlying Chodenice and Grabowiec beds are uplifted, and the overall structure may be described as a triangle zone, filled by deformed Skawina Beds, with the backthrust developed along the ductile evaporitic level. Farther to the north, sub-evaporitic deposits are rather thin and form only a thin veneer above the Meso-Paleozoic basement. The supra-evaporitic Chodenice and Grabowiec beds make up the bulk of the foredeep deposits in this part of the foredeep basin. They have not undergone any significant compressional deformation during the final Carpathian thrusting movements. They are characterized by an approximately internal configuration parallel to the evaporites and deeper basement, and, farther to the north, by an inclined seismic pattern, with a clearly visible angular unconformity above the evaporites. Such internal geometry could be interpreted as an effect of overall sediment progradation from the south towards the north, similarly to the depositional model proposed for the part of the foredeep located more to the east, in the Wojnicz-Tarnów area (Krzywiec, 2001; cf. Oszczypko et al., 2006).

Two other seismic profiles have been selected to more precisely illustrate the internal structure of the Gdów "embayment" (Fig. 6). The first of them (Fig. 6A) is located in its more central part and is calibrated by several boreholes (cf. Fig. 3). The Ksią nice 2 borehole provides crucial stratigraphic information on the precise location of the low-angle thrust fault de-

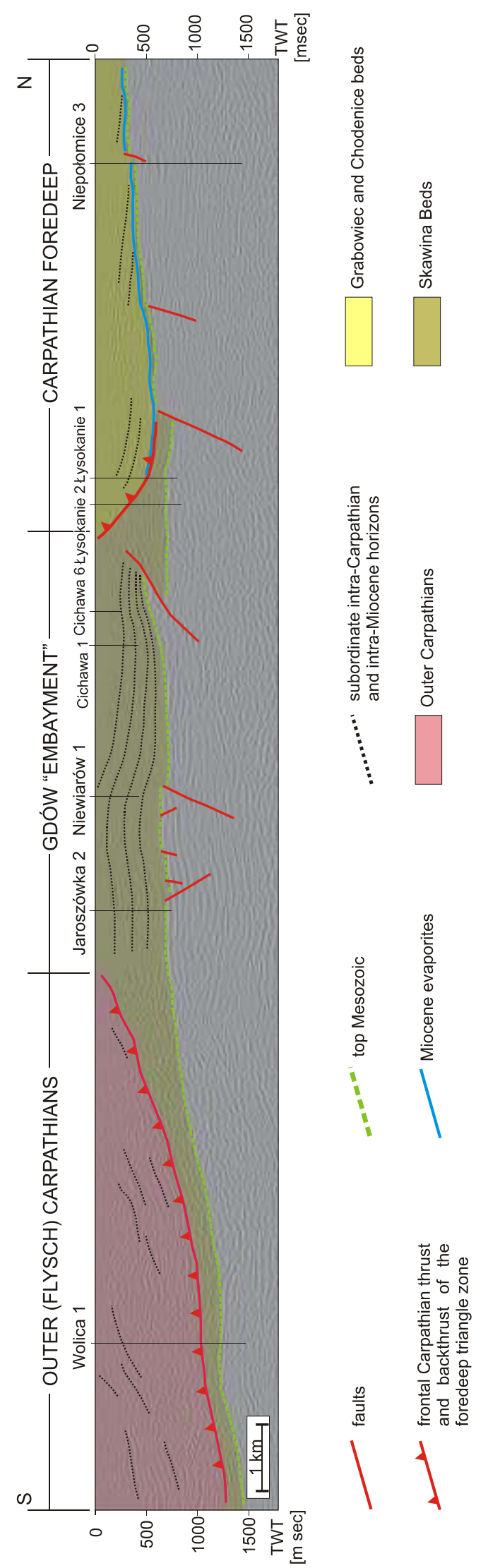

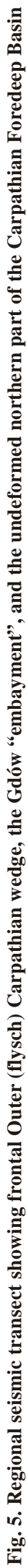



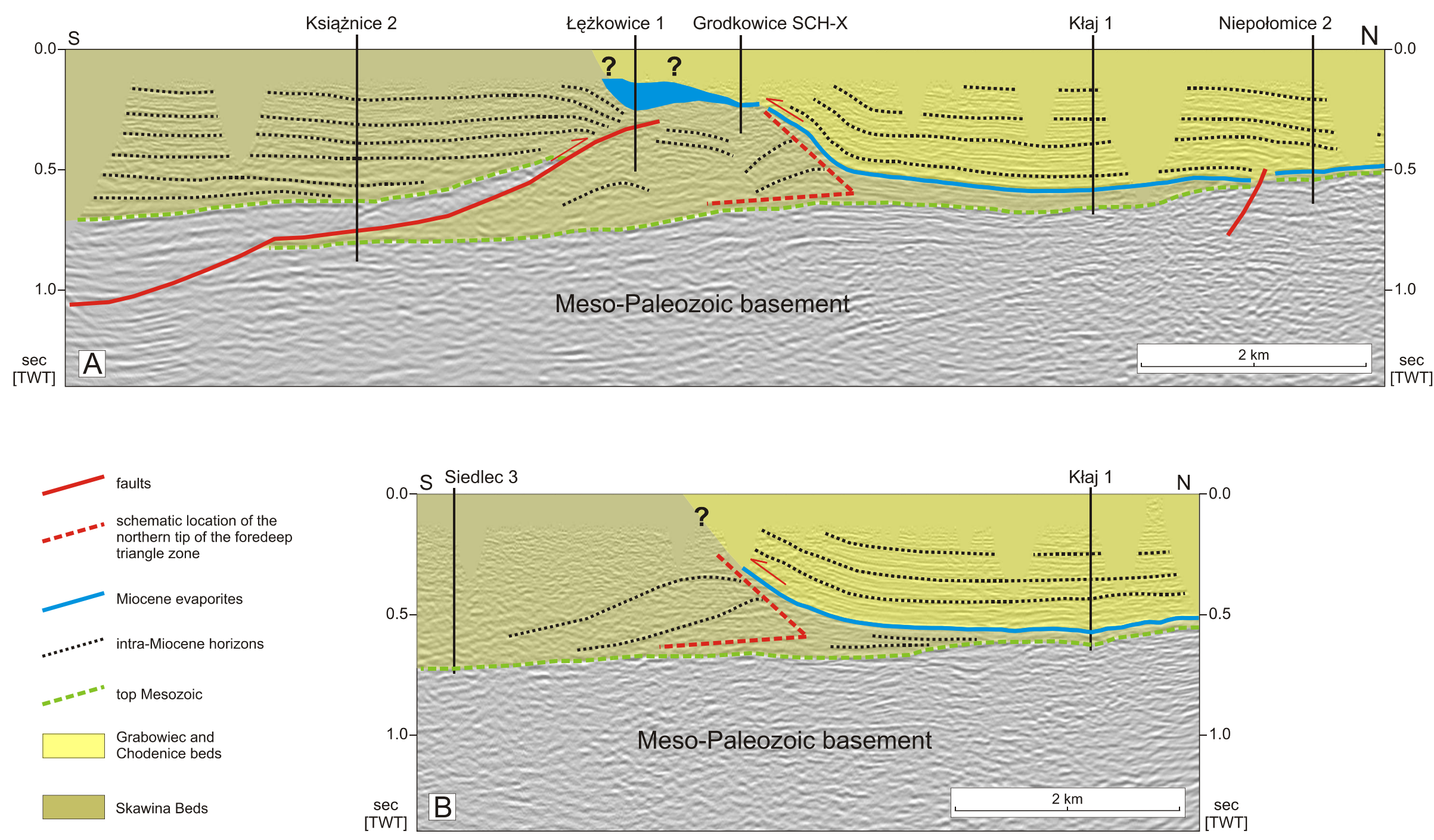

Fig. 6. Interpreted seismic profiles

A - central part of the Gdów "embayment". Note that due to the low quality of seismic data at shallower levels, structural interpretation of the Łe kowice-Grodkowice area, recognized from numerous boreholes drilled during exploration for rock salt, should be regarded as a first-order approximation only, partly based on published models (Garlicki, 1971); on this profile, as in the regional seismic transect shown on Figure 5, thick-skinned thrust faulting rooted in the Meso-Paleozoic basement can be observed. Such thrust faulting, confirmed also by several boreholes, has been already indicated by earlier studies (e.g., Połtowicz, 1962, 1991, 2004; Garlicki, 1971; Poborski and Jawor, 1987, 1989); B - eastern edge of the Gdów "embayment"; in this area, no thick-skinned thrust faulting has been observed within the Meso-Paleozoic basement; for location see Figure 3 
tached with the deeper (sub-Miocene) basement. Boreholes from the Łę kowice-Grodkowice area provided information on deformed thick evaporites located at shallow depths (cf. Garlicki, 1971). It should be stressed, however, that due to the low quality of seismic data at shallower levels, the exact structural interpretation of the evaporites in the Łę kowice-Grodkowice area should be regarded as a first-order approximation only, partly based on published models (Garlicki, 1971). The Skawina Beds within the Gdów "embayment" are generally only gently deformed and preserve pre-deformational internal depositional geometry. The only exception is the most northern tip of the "embayment", where all the Miocene deposits are strongly deformed. Evaporites with their siliciclastic cover of the Chodenice and Grabowiec beds are concordantly uplifted along the trailing edge of the Gdów "embayment”, similarly to what has been observed on the regional transect described above (Fig. 5). Farther to the north, evaporites are underlain only by a thin veneer of the sub-evaporitic deposits. A very similar structure of the Miocene foredeep deposits could be observed on the second profile, located within the eastern part of the Gdów "embayment" (Fig. 6B). On this profile one can also observe thick Skawina Beds, stratigraphicaly documented by the Siedlec 3 borehole (Euczkowska, 1958), that along the trailing edge of the Gdów "embayment" are compressionally deformed. Above this zone of relatively strong deformation, evaporites together with the supra-evaporitic Chodenice and Grabowiec beds are locally uplifted. The main difference between these two profiles is the presence (Fig. 6A) or lack (Fig. $6 \mathrm{~B})$ of the thick-skinned thrust faults rooted within the MesoPaleozoic basement. The triangular geometry of the zone of the deformed Skawina Beds beneath the uplifted evaporites and supra-evaporitic siliciclastics may be interpreted, similarly to what has been described above for the regional seismic transect, as a triangle zone related to the wedge tectonics active during last stages of the Carpathian thrusting (cf. Krzywiec et al., 2004, Krzywiec and Vergés, 2007). Supra-evaporitic siliciclastic deposits are backthrust towards the south along the detachment related to the foredeep evaporites. Seismic imaging of the triangle zone itself is not very good, although one can observe traces of fold structures present in the northern corner of the triangle zone.

\section{MIOCENE EVOLUTION OF THE GDÓW "EMBAYMENT" AREA - A MODEL}

A general model for the Miocene evolution of the Gdów "embayment" was constructed using the interpreted seismic data described above and is shown on Figure 7. It was constructed using the central part of the regional transect from Figure 5.

The model consists of three main stages, each associated with development of the three main building blocks of the sedimentary infill of this part of the Carpathian Foredeep: the Skawina Beds, the evaporitic Wieliczka Formation and finally the Chodenice and Grabowiec beds of the Machów Formation (cf. Fig. 2).

The first stage of evolution of the Gdów "embayment” was associated with deposition of the Skawina Beds (Fig. 7A). These are mostly clayey-sandy deposits, but significant in- crease in coarser material could be observed in the southern part of the "embayment" (Doktor, 1983). The thick (up to 1000 m) Lower Badenian Skawina Beds within the Gdów "embayment" have their stratigraphic equivalent in the more northern part of the Carpathian Foredeep Basin i.e. the Baranów Beds (cf. Oszczypko et al., 2006). They are, however, characterized by much smaller thickness, ca. 30-40 m or less (Ney et al., 1974) and are schematically shown on Figure 7A as a very thin veneer of siliciclastic deposits developed above the Meso-Paleozoic basement. The reconstructed geometry of the Gdów "embayment" during deposition of the Skawina Beds (Fig. 7A) suggests that increased thickness of the sedimentary infill was controlled by localized tectonic activity of this part of the foredeep basin. Some sub-Miocene faults might have directly controlled deposition of the Skawina Beds; additionally, flexural subsidence was responsible for a general thickness increase towards the south, i.e. towards the Carpathians. The presence of coarser material in the southern part of the Skawina Beds within the Gdów "embayment" clearly indicates relatively short transport and proximity of the source area i.e. emerged Carpathian thrust sheets (Alexandrowicz, 1965; Doktor, 1983).

During the next stage of development of the Gdów "embayment", upper Badenian evaporites of the Wieliczka Formation were deposited (Fig. 7B). Their inferred thickness is smaller than the thickness of the underlying Lower Badenian Skawina Beds; they are, however, also characterized by lateral thickness variations, similarly to the Skawina Beds. Within the Gdów "embayment" evaporites might have attained larger thickness, while towards the north they form a generally thin veneer. It is postulated that such local thickness increase of the evaporitic cover within the Gdów "embayment" areas was also related to tectonic activity of some basement faults (cf. Fig. 7B). Such model is fully compatible with the earlier model proposed by Garlicki (1971) for the Łę kowice area.

The third stage of the proposed evolution of the area of the present-day Gdów "embayment" shown on Figure 7C was associated with deposition of the Chodenice and Grabowiec beds of the Machów Formation (cf. Fig. 2). These deposits have been generally shed towards the Carpathian Foredeep Basin from the emerged and eroded Carpathians (e.g., Oszczypko et al., 2006). Within the present-day southern and central parts of the basin they are characterized by an overall progradational pattern directed towards the north (cf. Krzywiec, 2001; Porębski et al., 2002; Porębski and Steel, 2003). Such general depositional architecture of the supra-evaporitic siliciclastic cover of the Carpathian Foredeep in front of the Carpathian thrust belt is clearly visible on the regional transect in Figure 5.

Within the Gdów "embayment” area, due to the later uplift and erosion (see below), only evaporites are locally preserved at the surface (cf. Bukowski et al., 2010).

During the final stages of development of the Carpathian fold-and-thrust wedge the previously subsiding Gdów "embayment" area was uplifted and basement faults were reactivated either as reverse or as low-angle thrust faults. As a result of this uplift, the entire foredeep succession deposited above the Skawina Beds (i.e., evaporites of the Wieliczka Formation and siliciclastics of the Machów Formation) has been removed by erosion. Only evaporites were locally preserved and may be 


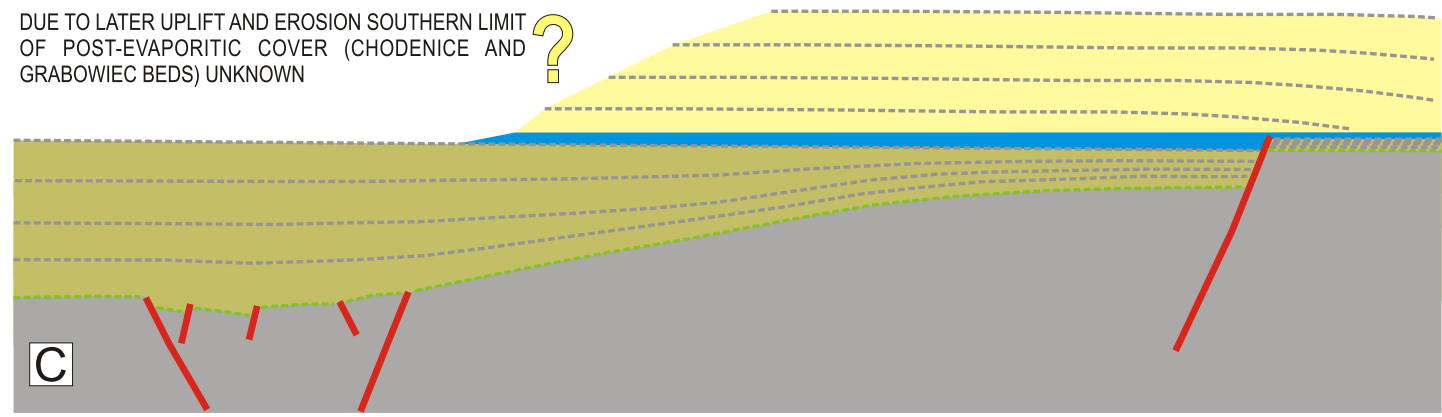

AREA OF LOCALLY INCREASED TECTONIC SUBSIDENCE WITHIN THE GDÓW "EMBAYMENT" DUE TO LATER UPLIFT AND EROSION SOUTHERN ?
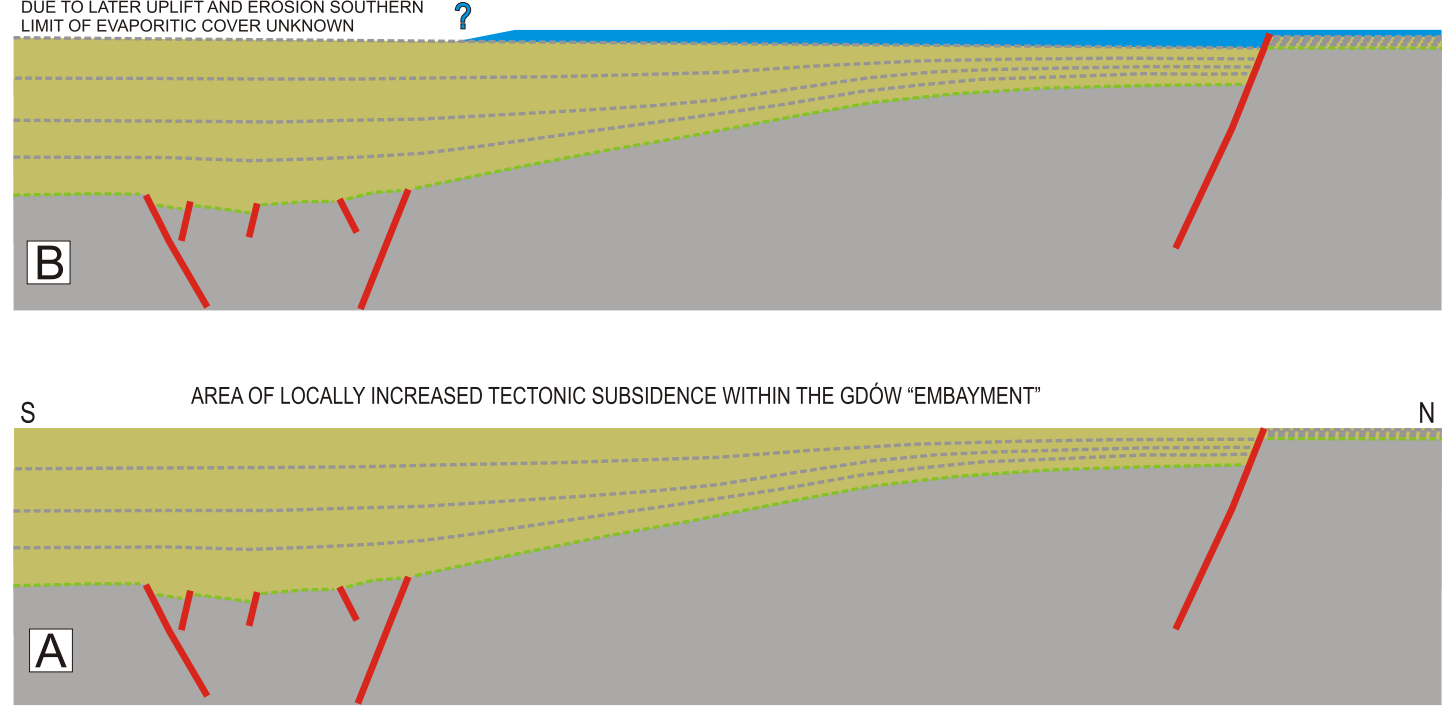

Fig. 7. Quantitative model of the three main stages of the Miocene evolution of the Gdów "embayment"

A - deposition of the Skawina Beds. Note that the lateral northern equivalent of this relatively thick infill of the Gdów "embayment" was also deposited but is characterized by relatively small thickness; B - deposition of evaporites of the Wieliczka Formation. Within the Gdów "embayment" they might have been characterized by increased thickness that later led to development of the Łę kowice rock salt deposit characterized by strong internal compressional deformation (Garlicki, 1960, 1971). Later uplift of the axial part of the Gdów "embayment" and subsequent erosion removed the southern part of the evaporitic cover, its exact southern edge not being known precisely (cf. Połtowicz, 1994); C - deposition of the Chodenice and Grabowiec beds, with inferred general sediment supply from the south (cf. Krzywiec, 2001; Oszczypko et al., 2006)

found at the surface in parts of the Gdów "embayment" area (see Bukowski et al., 2010 for more detailed description).

During final thrusting movements within the Carpathians, a triangle zone developed along the leading edge of inverted structure of the Gdów "embayment". Its formation was most probably influenced by the lateral thickness and facies changes in the transition zone between the "embayment" area characterized by thicker evaporites and the area located to the north, characterized by much thinner evaporitic cover. Such lateral changes of detachment level very often trigger formation of triangle zones (cf. Krzywiec and Aleksandrowski, 2004). Backthrust of the triangle zone present along the northern edge of the Gdów "embayment" formed along the evaporitic level (Figs. 5 and 6). Locally, during such backthrusting, over thickened evaporites formed in tectoni cally-controlled depression within the Gdów "embayment" area (Fig. 7B) have been strongly folded and internally deformed. Such deformations are documented by numerous boreholes from the Cię kowice-Grodkowice area (Garlicki, 1971).

\section{DISCUSSION AND CONCLUSIONS}

The model of evolution of the Gdów "embayment" presented in this paper was constructed using relatively good quality seismic data calibrated by numerous boreholes and augmented by surface geological data. To a large degree, it supports one of the earlier models postulated by Garlicki (1971), and that was later challenged (Poborski and Jawor, 1987, 1989; Połtowicz, 1991, 2004). In this model, the sedimentary infill of the Gdów "embayment" consists of the Skawina Beds, with only locally preserved remnants of the evaporitic cover at the surface. The formation of such thick Lower Badenian siliciclastic deposits has been attributed to localized tectonicallycontrolled subsidence, exerted either by local fault activity or by flexure of the lower plate under the advancing Carpathian orogenic wedge. The next stage of the Miocene evolution of this area includes a phase of deposition of the evaporitic cover that was also characterized by larger thickness within the Gdów "embayment" due to continuing locally increased and tectoni- 


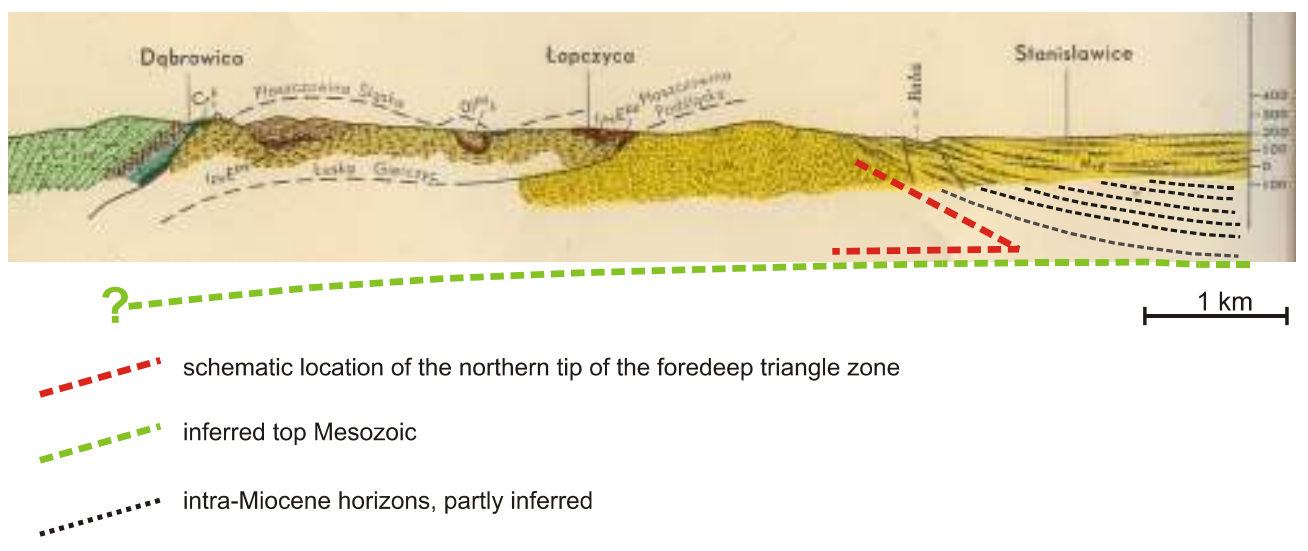

Fig. 8. Part of the geological cross-section from the geological 1:50 000 sheet "Bochnia", (Skoczylas-Ciszewska and Burtan, 1954) with added inferred location of top of the lower plate and inferred location of the hypothetical foredeep triangle zone

For location see Figure 3,

for additional explanations see Skoczylas-Ciszewska and Burtan (1954)

cally-controlled subsidence. The evaporites were overlain by siliciclastic deposits of the Machów Formation (Chodenice and Grabowiec beds) during the third stage of development of the study area. This siliciclastic cover was derived from the emerged and eroded Carpathian orogenic wedge. It should be however stressed that, due to late- and post-orogenic uplift and erosion, the second and third stages should be regarded as more conjectural than based on qualitative reconstructions.

The proposed model for development of the Gdów "embayment" includes also formation of the triangle zone along its northern edge during the last thrusting movements of the Carpathian orogenic wedge. This part of the model, based on reinterpreted seismic data and with reference points provided by models for the Wojnicz (Krzywiec et al., 2004) and Wieliczka (Krzywiec and Vergés, 2007) areas, is novel and different from all previously published models. However, in this context it is worth mentioning that the proposed structural interpretation of the northern edge of the Gdów "embayment" based on seismic data is in good agreement with the much earlier structural model of this area proposed by Skoczylas-Ciszewska and Burtan (1954; Fig. 8). On this cross-section one can observe a supra-evaporitic Miocene cover conformably uplifted above the older strongly deformed foredeep Miocene deposits. Due to the lack then of deeper wells in this area, and the lack of reliable subsurface geophysical (seismic) data Skoczylas-Ciszewska and Burtan (1954) did not show the top of the sub-Miocene Meso-
Paleozoic basement - Figure 7 shows its conjectural configuration. The key element of reinterpretation of this geological cross-section, shown on Figure 7, is the presence of a triangle zone along the leading (northern) edge of the Gdów "embayment", identical to the model proposed using seismic data and described in this paper. It should be also stressed that geological maps from the mid-XXth century were based on a large amount of surface geological data that are presently mostly unavailable due to increased surface anthropogenic infrastructure. Therefore, the geometry of the supra-evaporitic succession, concordantly uplifted towards the surface along the presumed backthrust developed within the frontal part of the Gdów "embayment" shown by Skoczylas-Ciszewska and Burtan (1954; Fig. 7) on their cross-section, should be regarded as generally reliable. This shows, together with the recent findings of Bukowski et al. (2010), that surface data support the model of the Gdów triangle zone filled by deformed Skawina Beds proposed in this paper.

Acknowledgements. This work has been carried out within the research project No 6 T12 2005 C/06569 funded jointly by PGNiG S.A. and the Ministry of Science and Higher Education. PGNiG S.A. is thanked for providing access to seismic data. A. Wysocka (University of Warsaw, Warsaw) and J. Vergés (Institute of Earth Sciences "Jaume Almera", Barcelona) are thanked for their thorough reviews that greatly helped to finally shape this paper.

\section{REFERENCES}

ABELS H.A., HILGEN F.J., KRIJGSMAN W., KRUK R.W., RAFFI I. TURCO E. and ZACHARIASSE W.J. (2005) - Long-period orbital control on middle Miocene global cooling. Integrated stratigraphy and astronomical tuning of the Blue Clay Formation on Malta. Paleoceanography, 20 (4): 1-17.
ALEXANDROWICZ S.W. (1963) - Zarys stratygrafii miocenu okolic Krakowa. Spraw. Pos. Kom. Nauk. PAN, Oddz. w Krakowie, 17: 520-523.

ALEXANDROWICZ S.W. (1965) - La Molasse miocene aux environs de Gdów. Bull. Acad. Pol. Sc., 13: 49-57. 
ALEXANDROWICZ S.W., GARLICKI A. and RUTKOWSKI J. (1982) Podstawowe jednostki litostratygraficzne miocenu zapadliska przedkarpackiego. Kwart. Geol., 26 (2): 470-471.

ANDREYEVA-GRIGOROVICH A.S., OSZCZYPKO N., ŚLACZKA A., SAVITSKAYA N.A. and TROFIMOVICH N.A. (2003) - Correlation of the Late Badenian salts of the Wieliczka, Bochnia and Kalush areas (Polish and Ukrainian Carpathian Foredeep). Ann. Soc. Geol. Pol., 73: 67-89.

BĄBEL M. (2004) - Badenian evaporite basin of the northern Carpathian Foredeep as a drawdown salina basin. Acta Geol. Pol., 54: 313-337.

BICCHI E., FERRERO E. and GONERA M. (2003) - Paleoclimatic interpretation based on Middle Miocene planktonic foraminifera: the Silesian Basin (Paratethys) and Monferrato (Tethys) record Palaeogeogr. Palaeoclimatol. Palaeoecol., 196: 263-303.

BUKOWSKI K. (2011) - Badenian saline sedimentation between Rybnik and Dębica based on geochemical, isotopic and radiometric research (in Polish with English summary). Dissert. Monogr., 236: 1-188.

BUKOWSKI K., de LEEUW A., GONERA M., KUIPER K.F., KRZYWIEC P. and PERYT D. (2010) - Badenian tuffite levels within the Carpathian orogenic front (Gdów-Bochnia area, Southern Poland) radio-isotopic dating and stratigraphic position. Geol. Quart., 54 (4): 449-464.

DE LEEUW A., BUKOWSKI K., KRIJGSMAN W. and KUIPER K.F. (2010) - Age of the Badenian salinity crisis; impact of Miocene climate variability on the circum-Mediterranean region. Geology, $\mathbf{3 8}$ 715-718.

DOKTOR M. (1983) - Sedimentation of Miocene gravel deposits in the Carpathian Foredeep (in Polish with English summary). Studia Geol. Pol., 68: 6-107.

D’OBYRN K. and PRZYBYŁO J. (2010) - Rozpoznanie geologiczne zło a soli kamiennej „Wieliczka” do 1945 roku. Prz. Górn., (3-4): $110-121$

GARLICKI A. (1960) - Rock salt deposit Łę kowice-Siedlec in Gdów "bay" (in Polish with English abstract). Prz. Geol., 8 (1): 43-45.

GARLICKI A. (1971) - Rock salt deposit at Łę kowice on Raba (in Polish with English summary). Kwart. Geol., 15 (4): 930-946.

GARLICKI A. (1979) - Sedimentation of Miocene salts in Poland (in Polish with English summary). Pr. Geol., 119: 1-66.

GĄGAŁA Ł., VERGÉS J., SAURA E., MALATA T., RINGENBACH J-C., WERNER P. and KRZYWIEC P. (2012) - Architecture and orogenic evolution of the northeastern Outer Carpathians from cross-section balancing and forward modeling. Tectonophysics, 532-535: 223-241

GONERA M. (1994) - Palaeoecology of marine Middle Miocene (Badenian) in the Polish Carpathians (Central Paratethys). Foraminifera record. Bull. Pol. Acad. Sc. Earth Sc., 42 (2): 107-125.

GONERA M. and BUKOWSKI K. (2012) - Isotopic events in the Early/Middle Badenian (Miocene) of Silesia Basin (Central Paratethys). Geol. Quart., 56 (3): 561-568.

GONERA M., OSZCZYPKO N. and ZUCHIEWICZ W. (1990) - Profil utworów badeńskich w rejonie Wrząsowic na SE od Krakowa. Sprawozd. Pos. Kom. Nauk Geol. PAN Oddz. w Krakowie, 34 (1/2): 211-215

GONERA M., PERYT T.M. and DURAKIEWICZ T. (2000) Biostratigraphical and palaeoenvironmental implications of isotopic studies ${ }^{18} \mathrm{O},{ }^{13} \mathrm{C}$ of middle Miocene Badenian foraminifers in the Central Paratethys. Terra Nova, 12: 231-238.

HILGEN F.J., ABELS H.A., IACCARINO S, KRIJGSMAN W., RAFFI I., SPROVIERI R., TURCO E. and ZACHARIASSE W.J. (2009) The Global Stratotype Section and Point (GSSP) of the Serravallian Stage (Middle Miocene). Episodes, 32: 152-166.

HRDINA J.N. and HRDINA L.E. (1842) - Geschichte der Wieliczkaer Saline. Wien. Carl Gerold: 274 pp.

JASIONOWSKI M. (1997) - Lithostratigraphy of the Miocene deposits in the eastern part of the Carpathian Foredeep (in Polish with English abstract). Biul. Państw. Inst. Geol., 375: 43-60.

JASIONOWSKI M. and PERYT T.M. (2010) - Isotopic composition of dolomite associated with Middle Miocene Badenian anhydrites in the Carpathian Foredeep Basin of SE Poland. Geol. Quart., 54 (4): 533-548.
JONES P. (1997) - The Carpathians of the southern Poland: thrust tectonics or wedge tectonics (abs.): 1997 AAPG International Conference and Exhibition, Austria, Vienna, Abstract book: A27-A28.

KASPRZYK A. (1993) - Lithofacies and sedimentation of the Badenian (middle Miocene) gypsum in the northern part of the Carpathian Foredeep, southern Poland. Ann. Soc. Geol. Pol., 63: 33-84.

KOTLARCZYK J. (1985) - An outline of the stratigraphy of Marginal Tectonic Units of the Carpathian Orogene in the Rzeszów-Przemyśl area. In: Geotraverse Kraków-Baranów-Rzeszów-Przemyśl-Komańcza-Dukla. Guide to excursion 4 (ed. J. Kotlarczyk): 21-32. XIII Congr. Carpath.-Balkan Geol. Ass., Cracow, Poland.

KOVÁČ M., NAGYMAROSY A., OSZCZYPKO N., ŚLACZKA A. CSONTOS L., MARUNTEANU M., MATENCO L. and MARTON E. (1998) - Palinspastic reconstruction of the Carpathian-Pannonian region during the Miocene. In: Geodynamic Development of the Western Carpathians: Bratislava (ed. M. Rakus): 189-217. Slovak Geological Survey.

KRZYWIEC P. (2001) - Contrasting tectonic and sedimentary history of the central and eastern parts of the Polish Carpathian Foredeep Basin results of seismic data interpretation. Mar. Petrol. Geol., 18 (1): 13-38.

KRZYWIEC P. and ALEKSANDROWSKI P. (2004) - Wedge tectonics and triangle zones - basic concepts (in Polish with English abstract). Prz. Geol., 52 (10): 985-989.

KRZYWIEC P. and VERGÉS J. (2007) - Role of the foredeep evaporites in wedge tectonics and formation of triangle zones: Comparison of the Carpathian and Pyrenean Thrust Fronts. In: Thrust Belts and Foreland Basins - from Fold Kinematics to Petroleum Systems (eds. O. Lacombe, J. Lavé, F. Roure and J. Vergés): 383-394. New Frontiers in Earth Sciences, Springer Verlag.

KRZYWIEC P., ALEKSANDROWSKI P., FLOREK R. and SIUPIK J. (2004) - The structure of the Outer Carpathian orogenic front: an example of the Miocene Zgłobice unit between Brzesko and Wojnicz new data, new models, new questions (in Polish with English summary). Prz. Geol., 52 (11): 1051-1059.

ŁUCZKOWSKA E. (1958) - The Miocene microfauna of the Carpathian Foredeep (in Polish with English summary). Kwart. Geol., 2 (1): $105-126$.

MORYC W. (1970a) - Katalog wierceń Górnictwa Naftowego w Polsce. Przedgórze Karpat - część zachodnia, t. I, cz. 3. Wyd. Geol., Warszawa.

MORYC W. (1970b) - Katalog wierceń Górnictwa Naftowego w Polsce Przedgórze Karpat - część zachodnia, t. I, cz. 4. Wyd. Geol., Warszawa.

NEY R., BURZEWSKI W., BACHLEDA T., GÓRECKI W., JAKÓBCZAK K. and SŁUPCZYŃSKI K. (1974) - Outline of paleogeography and evolution of lithology and facies of Miocene layers in the Carpathian Foredeep (in Polish with English summary). Pr. Geol., 82: $1-65$.

NIEDŹWIEDZKI J. (1883-1886) - Stosunki geologiczne formacyi solonośnej Wieliczki i Bochni. Kosmos, 8 (1883): 137-159, 387-401, 483-492; 9 (1884): 565-580, 717-743; 11 (1886): 137-155.

OLEWICZ Z.R. (1973a) - Geology of the Fore-Carpathian region between Wieliczka and Bochnia (in Polish with English summary). Pr. Inst Naft.

OLEWICZ Z.R. (1973b) - Tectonic structure of the Bochnia Unit and of the marginal part of the Silesian Unit between the rivers Raba and Uszwica (in Polish with English summary). Acta Geol. Pol., 23 (4): 701-761.

OSZCZYPKO N. (1997) - The Early-Middle Miocene Carpathian peripheral foreland basin (Western Carpathians, Poland). Prz. Geol., 45: 1054-1063.

OSZCZYPKO N. (1998) - The Western Carpathian foredeep-development of the foreland basin in front of the accretionary wedge and its burial history (Poland). Geol. Carpath., 49: 1-18.

OSZCZYPKO N. (1999) - The Miocene subsidence of the Polish Carpathian Foredeep (in Polish with English summary). Pr. Państ. Inst. Geol., 168: 209-230.

OSZCZYPKO N. and OSZCZYPKO-CLOWES M. ( 2012) - Stages of development in the Polish Carpathian Foredeep Basin. Centr. Eur. J. Geosc., 4 (1): 138-162. 
OSZCZYPKO N., OLSZEWSKA B., ŚLEZAK J. and STRZĘPKA J. (1992) - Miocene marine and brackish deposits of the Nowy Sącz basin (Polish Western Carpathians) - new lithostratigraphic and biostratigraphic standards. Bull. Pol. Acad. Sc., Earth Sc., 40: 83-96.

OSZCZYPKO N., KRZYWIEC P., POPADYUK I. and PERYT T. (2006) Carpathian Foredeep Basin (Poland and Ukraine) - its sedimentary, structural and geodynamic evolution. AAPG Mem., 84: 293-350.

OSZCZYPKO-CLOWES M. OSZCZYPKO N. and WÓJCIK A. (2009) New data on the late Badenian-Sarmatian deposits of the Nowy Sacz Basin (Magura Nappe, Polish Outer Carpathians) and their palaeogeographical implications. Geol. Quart., 53 (3) 273-292.

PERYT D. (1997) - Calcareous nannoplankton stratigraphy of the Middle Miocene in the Gliwice area (Upper Silesia, Poland). Bull. Pol. Acad. Sc., Earth Sc., 45: 119-131.

PERYT D. and GEDL P. (2010) - Palaeoenvironmental changes preceding the Middle Miocene Badenian salinity crisis in the northern Polish Carpathian Foredeep Basin (Borków quarry) inferred from foraminifers and dinoflagellate cysts. Geol. Quart., 54 (4): 487-508.

PERYT T.M. (2006) - The beginning, development and termination of the Middle Miocene Badenian salinity crisis in Central Paratethys. Sedim. Geol., 188-189: 379-396.

PERYT T.M., HAŁAS S., KAROLI S. and PERYT D. (1997) - Isotopic record of environmental changes during deposition of Badenian (Middle Miocene) gypsum at Kobeřice near Opava (Czech Republic) (in Polish with English summary). Prz. Geol., 45 (8): 807-811.

POBORSKI J. (1965) - Historical development of views on the geological structure of the salt beds of Wieliczka (in Polish with English summary). Studia i materiały do dziejów up solnych w Polsce, 1: 37-54.

POBORSKI J. and JAWOR E. (1987) - Old basement of the Miocene salt-bearing formation in the vicinities of Gdow (Podkarpacie Region). Bull. Acad. Pol. Sc., 35 (3): 215-219.

POBORSKI J. and JAWOR E. (1989) - Notes on the Cracow sub-Carpathian tectonics (in Polish with English summary). Prz. Geol., 37 (6): 308-311.

POŁTOWICZ S. (1962) - Outline of the tectonic structure of the Bay of Gdów. Bull. Acad. Pol. Sc., Ser. Sc. Geol. Géogr., 10 (1): 53-60.

POŁTOWICZ S. (1991) - Miocene of the Carpathian Zone between Wieliczka and Dębica (in Polish with English summary). Geologia, 17 (3): 19-57.

POŁTOWICZ S. (1994) - Znaczenie badeńskiej formacji solonośnej w tektogenezie polskich Karpat brze nych. Geologia. Kwart. AGH, 20 (1): 59-76
POŁTOWICZ S. (2004) - The Stebnik and Zgłobice Units in the Polish Carpathians structure (in Polish with English summary). Geologia, 30 (1): 85-120.

POREBSKI S. and STEEL R.J. (2003) - Shelf-margin deltas: their stratigraphic significance and relation to deepwater sands. Earth-Sc. Rev., 62: 283-326.

PORĘBSKI S., PIETSCH K., HODIAK R. and STEEL R.J. (2002) - Origin and sequential development of Badenian-Sarmatian clinoforms in the Carpathian foreland basin (SE Poland). Geol. Carpath., 54 (2): $119-136$.

PUSCH G.G. (1824) - Geognostisch-bergmännische Reise durch einen Theil der Karpathen, Ober- und Nieder-Ungarn ausgestellt im Jahre 1821. Johann Ambrosius Barth, Leipzig.

RAFFI I., BACKMAN J., FORNACIARI E., PALIKE H., RIO D. LOURENS L. and HILGEN F. (2006) - A review of calcareous nannofossil astrobiochronology encompassing the past 25 million years. Quatern. Sc. Rev., 25/23-24: 3113-3137.

SCHOBER C.G. (1750) - Physikalische Nachricht von den pohlnischen Salzgruben Wieliczka und Bochnia. Hamburgisches Magazin, 16: 115-155. Hamburg.

SKOCZYLAS-CISZEWSKA K. and BURTAN J. (1954) - Szczegółowa mapa geologiczna Polski w skali 1:50 000, ark. Bochnia (M34-77B). Inst. Geol., Warszawa.

TOWNSON R. (1797) - Travels in Hungary with a short account of Vienna in the year 1793. G.G. and J. Robinson, London, 506 pp.

ŚLIWIŃSKI M., BĄBEL M., NEJBERT K., OLSZEWSKA-NEJBERT D., GA_SIEWICZ A., SCHREIBER B.C., BENOWITZ J.A. and LAYER P. (2012) - Badenian-Sarmatian chronostratigraphy in the Polish Carpathian Foredeep. Palaeogeogr. Palaeoclimatol. Palaeoecol., 326-328: $12-29$.

UHLIG V. (1903) - Bau und Bild der Karpaten. V. Tempsky und G. Freytag, Wien und Leipzig.

YTKO K., GUCIK S., RYŁKO W., OSZCZYPKO N., ZAJAC R., GARLICKA I., NEMCOK J., ELIAS M., MENCIK E., DVORAK J. STRANIK Z., RAKUS M. and MATEJOVSKA O. (1989) - Geological map of the Western Outer Carpathians and their foreland without Quaternary formations (1:500 000). In: Geological Atlas of the Western Outer Carpathians and their Foreland (eds. D. Poprawa and J. Nemcok). Państw. Inst. Geol., Warszawa. 